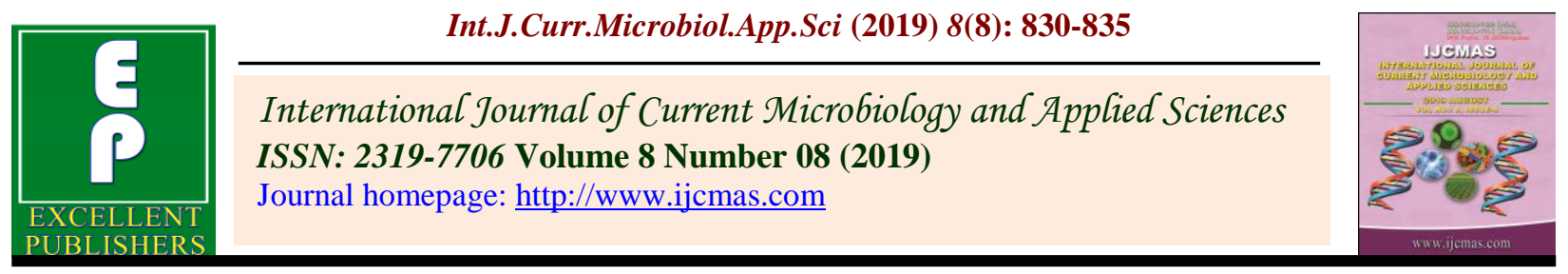

Original Research Article

https://doi.org/10.20546/ijcmas.2019.808.095

\title{
Effect of Plant Extracts on Seed Germination Behaviour and Vigour of Okra [Abelmoschus esculentus (L.) Moench]
}

\author{
Indrajitsingh P. Girase*, Prashant Kumar Rai, Bineeta M. Bara and Bazil A. Singh \\ Department of Genetics and Plant Beeding, Sam Higginbottom University of Agriculture, \\ Technology and Sciences, Prayagraj, 211007 U. P., India \\ *Corresponding author
}

Ke y w or d s
Leaf extracts, Okra,
Phule vimucta, Seed
quality, Seed
priming

Article Info

Accepted:

07 July 2019

Available Online:

10 August 2019

\section{A B S T R A C T}

The seed of okra [Abelmoschus esculentus (L.) Moench] have slow and poor germination when seeds are sown in early spring season due to low temperature. Laboratory experiment was conducted to study the effect of seed priming using plant extract on seed quality characters of okra. Various botanical leaf extracts used like Arjuna, Bael, Harad, Bahed, Arrapu, Neem, Reetha, Amla, Tulsi, Prosopis and Cow urine on seedling quality characters of phule vimucta variety of okra. The result concluded that priming with Arrapu (Albizia amara) Leaf Extract at (3\%) for $12 \mathrm{hrs}$ increased the germination and seed vigour in Okra. Its exhibited high mean value for Seedling characters like seed germination percentage $(96.50 \%)$, Speed of germination (09.77), root length $(12.22 \mathrm{~cm})$, shoot length $(16.39 \mathrm{~cm})$, seedling length $(28.80)$, seedling fresh weight $(1.03 \mathrm{gm})$ and seedling dry weight $(0.35 \mathrm{gm})$, seed vigour index I (2427.95) and seed vigour index II (19.36).

\section{Introduction}

Okra is one of the most widely known and utilized species of the family Malvaceae (Naveed et al., 2009). This crop is suitable for cultivation as a garden crop as well as on large commercial farms. It is grown commercially in India, but its original home is Ethiopia and Sudan. In Indian cooking, it is sauteed or added to gravy-based preparations. It medicinally used as plasma replacement or blood volume expander. Industrially, mucilage is usually used to glace certain papers and also useful in confectionary (Benchasri, 2012). It provides an important source of vitamins, calcium, potassium and other mineral matters (IBPGR, 1990). Also called "a perfect villager's vegetable" due to robust nature and presence of fibre in the form of gums and pectin.

When these okra seeds are sown in early spring season, they show poor germination due to low temperature. Another major problem in germination of okra seeds is hard seed coat which restricts the water imbibition and uniform growth and development of embryo (Mereddy et al., 2000).

Seed priming has presented promising, and even surprising results, for many crop seeds 
(Bradford, 1986). Seed priming is a presowing seed treatment in which seeds are allowed to imbibe water to start pregerminative metabolic processes but insufficient for radical protrusion and also helps to soften the hard seed coat. The activity of many enzymes involved in mobilization of food reserves is triggered (Srinivasan et al., 2009). Seed deterioration can be controlled through priming prior to storage because priming activates antioxidant enzymes examples like catalase, peroxidase, superoxidase and lowers per-oxidation in seed (Rahman et al., 2013). (Moosavi et al., 2009) reported that primed seeds significantly improved the germination percentage, speed of germination, root length and seed vigor.

Botanical seed treatment is a liquid formulation it has synergistic effect on early and uniform seed germination and enhances tolerance to pest and disease during early crop stage. Microbes are effective in inducing plant growth as they secrets plant growth and enhance seed germination and root growth. Hence, present studies were undertaken to determine the effect of plant extracts on germination and vigours characters of okra in early spring season.

\section{Materials and Methods}

Seed of okra of variety Phule Vimukta, obtained from Mahatma Phule Krishi Vidyapeeth, Rahuri, Maharashtra, India and the fresh leaves of Arjuna, Bael, Harad, Baheda, Arrapu, Neem, Reetha, Amla, Tulsi and Prosopis were collected from K.C. Ajmera Ayurved Mahavidyalaya for conducting experiment. Present investigation was carried out at Post- Graduate Laboratory of Department of Genetics and Plant Breeding, Sam Higginbottom, University of Agriculture, Technology and Sciences, Paryagraj (U.P.) during 2018-2019.

\section{Procedure of preparation of leaf extracts}

Make the powdered of separately shade dried leaves using electric grinder. Take three gram Powder and dissolved in $100 \mathrm{ml}$ of distilled water to make 3 per cent leaf extract solution. These solutions were kept at room temperature for 48 hours. After 48 hours the leaf extracts were filtered by two layer of muslin cloth to remove unwanted material and leaf debris. Seeds were soaked independently in different leaf extracts at room temperature for twelve hours.

\section{Preparation of cow urine extract}

Locally available cow urine is used for organic seed priming which acts as growth promoter by preventing plant disease. $3 \mathrm{ml}$ of cow urine were added separately in $100 \mathrm{ml}$ water to get $3 \%$ of solution which were used for seed treatment.

For seedling characters, the germination test was conducted using three replications of 100 seeds from each sample in sand and between paper methods as per procedure described by ISTA (1999). Seedling dry weight and vigour index I and II were determined by Baki and Anderson (1973).

\section{Treatment details}

$\mathrm{T}_{0}-$ Control

$\mathrm{T}_{1}$ - Terminalia arjuna Leaf Extract@ 3\%

$\mathrm{T}_{2}$-Aegle marmelos Leaf Extract@3\%

$\mathrm{T}_{3}$-Terminalia chebula Leaf Extract@3\%

$\mathrm{T}_{4}$ - Terminalia bellirica Leaf Extract@ 3\%

$\mathrm{T}_{5}$ - Albizia amara Leaf Extract@3\%

$\mathrm{T}_{6}$-Azadirachta indica Leaf Extract@3\%

$\mathrm{T}_{7}$-Sapindus mukorossi Leaf Extract@3\%

$\mathrm{T}_{8}$ - Phyllanthus emblica Leaf Extract@3\%

$\mathrm{T}_{9-}$ Ocimum tenuiflorum Leaf Extract@ 3\%

$\mathrm{T}_{10}$ - Prosops juliflora Leaf Extract@ 3\%

$\mathrm{T}_{11}$ - Cow Urine@ 3\% 


\section{Data analysis}

In order to calculate the Germination (\%), Speed of Germination, Shoot, Root and Seedling length, Seedling Fresh and Dry Weight, Vigour Index (I and II), by formula 1, formula 2 , formula 3 , formula 4 , formula 5 and formula 6 were used:

Germination $\%=\frac{\text { Number of germinated seeds }}{\text { Totalnumber of seeds sown }} \times 100$

S.P $=\frac{G_{1}}{D_{1}}+\frac{G_{2}}{D_{2}}+\ldots \ldots \ldots . . .+\frac{G_{n}}{D_{n}}$

Root and shoot length: Root and shoot length of five fresh seedlings was measured in centimeters up to one decimal. Total seedling length was calculated by adding root and shoot length.

Seedling dry weight: The seedlings used for recording were dried in an oven at $103^{\circ} \mathrm{C}$ for 12 hours. Measurement of dried samples was record on an electronic balance upto three decimals in gm.

V.I. (I) = Germination percentage (Normal seedling) X Seedling length $(\mathrm{cm})$

V. I. (II) = Germination percentage (Normal seedling) X Dry weight of the seedling (gm)

\section{Result and Discussion}

\section{Effect of plant extracts on germination}

In the present study, seeds of okra priming with different plant leaf extracts and used for sowing. Presowing seed priming has a positive significance which is influences the germination and viability characters of okra. Albizia amara Leaf Extract3\% primed seed $\left(\mathrm{T}_{5}\right)$ recorded maximum germination percentage (96.50) and the untreated seed $\left(\mathrm{T}_{0}\right)$ recorded minimum germination percentage (88.25). High speed of germination observed in $\left(\mathrm{T}_{5}\right)$ Albizia amara Leaf Extract $3 \%$ primed seed (9.77) and minimum speed found in $\left(\mathrm{T}_{3}\right)$ Terminalia chebula Leaf Extract 3\% primed seed (7.15). Many researchers suggested that highest germination observed due to large amount of microbes presents in plant extracts and microbes are effective in inducing plant growth as they secrets plant growth promoters (auxins, abscisic acid, gibberellic acid, cytokines, and ethylene) and enhance seed germination and increase the speed of germination. Leaf of Albizia amara presence of wide variety of bioactive compounds such as alkaloids, triterpene saponins, phenols, flavonyl glycosides, tannins, sterols In addition, the plant extract possess the pharmacological properties like antihyperlipidimic, antiinflammatory, antimicrobial, analgesic and antioxidant activities (Indravathi et al., 2013). (Vadivelu et al., 1985) concluded Bengal gram seed treated with arappu leaf powder @ $50 \mathrm{~g} \mathrm{~kg}^{-1}$ of seed maintained germination up to two seasons.

Effect of plant extracts on growth (shoot length, root length and seedling length)

Shoot length and root length of okra influenced significantly by the extracts of different plant leaves. Shoot length of okra to be maximum with the treatment $\left(\mathrm{T}_{5}\right)$ leaf extract of Albizia amara Leaf Extract3\% primed seed $(16.39 \mathrm{~cm})$ and maximum root length also recorded in treatment $\left(\mathrm{T}_{5}\right)$ leaf extract of Albizia amara Leaf Extract 3\% primed seed $(12.22 \mathrm{~cm})$. Seedling length is related to shoot and root length i.e seedling length also recorded higher in $\left(\mathrm{T}_{5}\right)$ Albizia amara Leaf Extract3\% primed seed (28.80 $\mathrm{cm})$. The other treatments showed moderate performance except the treatment $\left(\mathrm{T}_{10}\right)$ leaf extract of Prosops juliflora $(10.14 \mathrm{~cm})$ and treatment $\left(\mathrm{T}_{4}\right)$ Terminalia bellirica $(10.45 \mathrm{~cm})$ which found to decreased the shoot, root length respectively comparison with control. Results also demonstrated the inhibitory effect of aqueous leaf extract of treatment $\left(\mathrm{T}_{6}\right)$ 
Azadirachta indica 3\% primed seed on growth (seedling length) in okra $(21.44 \mathrm{~cm})$.

Sarika et al., (2013) conducted a lab experiment to study various physiological and biochemical changes by priming in French bean at Bangalore. They reported that herbal priming with different leaf extract improved the seed quality and showed improved seedling length, seedling dry weight which in turn improved higher seedling vigour index, germination speed and mean germination time.

As per (Salam et al., 2010) neem leaves may contain growth inhibitory substances and may possess allelopathic potential. Therefore, neem leaves may be a possible candidate for the isolation and identification of allelopathic substances and for the development of natural herbicides for sustainable agricultural production

Effect of plant extracts on seedling weight and vigour index

This result of study indicates that okra seedlings which are exposed to various seed priming treatments have shown increase in fresh, dry weight content and vigour index.

Table.1 Effect of different plant extracts on seed quality parameters of okra

\begin{tabular}{|c|c|c|c|c|c|c|c|c|c|}
\hline Treatments & $\begin{array}{c}\text { Germination } \\
\text { percentage }\end{array}$ & $\begin{array}{c}\text { Speed of } \\
\text { germination }\end{array}$ & $\begin{array}{c}\text { Root } \\
\text { length } \\
(\mathrm{cm})\end{array}$ & $\begin{array}{c}\text { Shoot } \\
\text { length } \\
\text { (cm) }\end{array}$ & $\begin{array}{l}\text { Seedling } \\
\text { length } \\
\text { (cm) }\end{array}$ & $\begin{array}{c}\text { Fresh } \\
\text { weight of } \\
\text { seedling } \\
\text { (g) }\end{array}$ & $\begin{array}{c}\text { Dry } \\
\text { weight of } \\
\text { seedling } \\
\text { (g) }\end{array}$ & $\begin{array}{l}\text { Seedling } \\
\text { vigour } \\
\text { index I }\end{array}$ & $\begin{array}{c}\text { Seedling } \\
\text { vigour } \\
\text { index II }\end{array}$ \\
\hline $\mathbf{T}_{\mathbf{0}}$ & 88.25 & 7.27 & 12.21 & 15.84 & 28.15 & 0.90 & 0.19 & $2,364.60$ & 17.52 \\
\hline $\mathbf{T}_{1}$ & 93.25 & 7.72 & 10.74 & 14.96 & 25.70 & 0.88 & 0.15 & $2,175.95$ & 12.71 \\
\hline $\mathbf{T}_{2}$ & 89.00 & 7.75 & 10.99 & 11.61 & 22.92 & 0.82 & 0.23 & $1,913.67$ & 16.14 \\
\hline $\mathbf{T}_{3}$ & 92.00 & 7.15 & 10.96 & 12.22 & 23.93 & 0.86 & 0.15 & $2,021.08$ & 12.66 \\
\hline $\mathbf{T}_{4}$ & 93.25 & 7.25 & 10.45 & 12.00 & 22.33 & 0.90 & 0.16 & $1,881.46$ & 13.40 \\
\hline $\mathbf{T}_{5}$ & 96.50 & 9.77 & 12.22 & 16.39 & 28.80 & 1.03 & 0.35 & $2,427.95$ & 19.36 \\
\hline$T_{6}$ & 95.50 & 8.87 & 10.87 & 10.57 & 21.44 & 1.02 & 0.17 & $1,794.56$ & 14.83 \\
\hline $\mathbf{T}_{7}$ & 91.00 & 8.25 & 11.85 & 12.24 & 24.07 & 0.84 & 0.17 & $2,040.94$ & 14.00 \\
\hline $\mathbf{T}_{8}$ & 93.00 & 8.37 & 12.15 & 11.17 & 23.33 & 0.77 & 0.22 & $2,047.90$ & 18.41 \\
\hline $\mathbf{T}_{9}$ & 92.50 & 7.60 & 10.84 & 11.17 & 21.73 & 0.98 & 0.19 & $1,920.65$ & 16.54 \\
\hline$T_{10}$ & 95.50 & 7.32 & 11.35 & 10.14 & 21.58 & 0.77 & 0.18 & $1,867.69$ & 15.17 \\
\hline$T_{11}$ & 92.36 & 7.63 & 11.51 & 13.29 & 23.82 & 0.63 & 0.20 & $2,200.01$ & 18.47 \\
\hline $\begin{array}{l}\text { Grand } \\
\text { Mean }\end{array}$ & 92.67 & 7.91 & 11.34 & 12.63 & 23.98 & 0.86 & 0.19 & $2,054.71$ & 15.76 \\
\hline CD 5\% & 1.88 & 1.52 & 0.76 & 0.81 & 1.42 & 0.12 & 0.02 & 183.00 & 3.41 \\
\hline S E & 0.65 & 0.52 & 0.26 & 0.28 & 0.49 & 0.04 & 1.34 & 63.32 & 1.18 \\
\hline CV & 1.40 & 13.29 & 4.68 & 4.48 & 4.09 & 9.32 & 153.97 & 6.20 & 15.20 \\
\hline \multirow[t]{2}{*}{ Range } & 96.50 & 9.77 & 12.22 & 16.39 & 28.80 & 1.03 & 0.35 & $2,427.95$ & 19.36 \\
\hline & 88.25 & 7.15 & 10.45 & 10.14 & 21.44 & 0.63 & 0.15 & $1,794.56$ & 12.66 \\
\hline
\end{tabular}


Vigour I and seedling vigour II were found for treatment $\left(\mathrm{T}_{5}\right)$ Albizia amara $3 \%$ extract primed seed followed by treatment $\left(\mathrm{T}_{11}\right)$ Cow Urine $3 \%$ primed seed (Table 1).

Renugadevi et al., (2008) also concluded that seed fortification with arappu leaf extract at one and two per cent concentrations for three hours expressed superior germination, vigour and field emergence in clusterbean.

As per the (Ambika et al., 2014) pre-sowing treatments with bovine urines of cow, buffalo, sheep, goat and pig. The paddy, maize, sorghum, cumbu and irungu cholam seeds (local type) were soaked for $3 \mathrm{~h}$ with different concentrations of 5 and $10 \%$ along with control (dry treatment). The seed quality parameters viz., speed of germination, germination percentage, seedling length $(\mathrm{cm})$ and vigour index were evaluated. Among the bovine urines treatment best performance was observed in cow urine $(5 \%)$ in all the cereals.

As a result of these studies, effect of plant extracts on seedling characters carefully observed. From the present study, it is suggest that the seeds primed with Albizia amara $3 \%$ leaf extract is recommended to enhance the seed quality parameters of okra.

\section{Acknowledgements}

Authors are thankful to Mahatma Phule Krishi Vidyapeeth (M.P.K.V), Rahuri for providing Phule Vimucta variety of okra seed. Sincere thanks to all the member, department of Genetics and Plant Breeding of Sam Hiiginbottom University of Agriculture, Technology and Sciences, Prayagraj, UP.

\section{References}

Abdul Baki, A.A. and Anderson, J.D. (1973). Vigour determination in soybean seeds by multiple criteria. Crop Science. 13: PP 630-633.
Ambika S., Balakrishnan K and Sujatha K. (2014). Enhancing the seed germination and vigour in coarse cereals by bovine urines. Journal of Agroecology and Natural Resource Management, 1(2): PP 40-43.

Benchasri S. (2012). Okra (Abelmoschus esculentus (L.) Moench) as a valuable vegetable of the world, Ratar. Povrt. 49:105-112.

Bradford, K.J., Steiner, J.J. and Trawatha, S.E. (2002). Seed priming influence on germination and emergence of pepper seed lots. Crop Science, 30: 718-721.

G. Indravathi, R. S. Reddy., Pakala S. B (2013). Albizia amara - A Potential Medicinal Plant: A Review, International Journal of Science and Research, 5(3): 621-627.

International Board for Plant Genetic Resources IBPGR (1990). Report on International Workshop on Okra Genetic resources held at the National bureau for Plant Genetic Resources, New Delhi, India.

ISTA (1999). "International rules for seed testing", Seed science and Technology, Vol. 27, pp. 25-30.

Md. Abdus Salam and Hisashi Kato-Noguchi (2010). Evaluation of Allelopathic Potential of Neem (Azadirachta indica. A. Juss) Against Seed Germination and Seedling Growth of Different Test Plant Species. International Journal of Sustainable Agriculture. 2 (2): 20-25.

Mereddy R, Wu L, Hallgren S W, Wu Y and Conway K E. (2000). Solid matrix priming Improves seedling vigour of okra seeds. Oklahoma Academy of Science. 80: 33-37.

Moosavi A., R. Tavakkol Afshari., F. SharifZadeh and A. Aynehband (2009). Effect of seed priming on germination characteristics, polyphenoloxidase, and peroxidase activities of four amaranth 
cultivars. Journal of Food, Agriculture \& Environment, 7 (3\&4): 353-358.

Naveed, A., Khan, A.A., \& Khan, I.A. (2009). Generation mean analysis of water stress tolerance in okra (Abelmoschus esculentus L.). Pak. J. Bot. 41: 195-205.

Rahman I U, Ali N, Rab A and Shah Z. (2013). Role of pre storage seed priming in controlling seed deterioration during storage. Sarhad Journal of Agriculture. 29: 379-386.

Renugadevi, J., Natarajan, N., and Srimathi, P. 2008. Efficacy of botanicals in improving the seeds and seedling quality characteristics of clusterbean. Legume Res. 31(3): 164-168.
Sarika G., Basavaraju G. V., Bhanuprakash K., Chaanakeshava V., Paramesh R. And Radha B. N. (2013). Investigation on seed viability and vigour of aged seed by priming in French bean. Vegetable Sci. 40: 169-73.

Srinivasan K, Jain S K, Saxena S, Radhamani J and Uprety M. (2009). Seed priming and fortification. Seed Res. 37: 1-13.

Vadivelu, K.K., Karivaratharaju, T.V., and Ramakrishnam, V. (1985). Influence of seed treatments, seed moisture content, containers on the viability of $\mathrm{CO} 1$ Bengal gram. Seed Res. 13(1): 39-49.

\section{How to cite this article:}

Indrajitsingh P. Girase, Prashant Kumar Rai, Bineeta M. Bara and Bazil A. Singh. 2019. Effect of Plant Extracts on Seed Germination Behaviour and Vigour of Okra [Abelmoschus esculentus (L.) Moench]. Int.J.Curr.Microbiol.App.Sci. 8(08): 830-835.

doi: https://doi.org/10.20546/ijcmas.2019.808.095 